\title{
Catalytic partial oxidation of methane to syngas over perovskite catalysts
}

\author{
Tan Ji Siang ${ }^{1}$, Aishah Abdul Jali1 ${ }^{1,2, *}$, Hambali Umar Hambali ${ }^{1}$, Ijaz Hussain ${ }^{1}$, and \\ Mohammad Saifulddin bin Mohd Azami ${ }^{1}$ \\ ${ }^{1}$ School of Chemical and Energy Engineering, Faculty of Engineering, Universiti Teknologi \\ Malaysia, 81310 Johor Bahru, Johor, Malaysia. \\ ${ }^{2}$ Centre of Hydrogen Energy, Institute of Future Energy, Universiti Teknologi Malaysia, 81310 Johor \\ Bahru, Johor, Malaysia.
}

\begin{abstract}
Partial oxidation of methane (POM) significantly offers benefits to the industrial production of syngas in comparison with other conventional processes in terms of hydrogen $\left(\mathrm{H}_{2}\right)$ /carbon monoxide $(\mathrm{CO})$ ratio and degree of catalyst deactivation induced by carbonaceous species. Thus, the increasing concern on commercialisation of POM technology has driven the catalyst system to enter another stage of developing a novel catalyst, namely perovskite. POM is comprehensively reviewed and compared with various perovskite catalysts. Apart from studying process chemistry to understand POM reaction, the role of metal types for perovskite structure on catalytic performance and coke selectivity are also scrutinised and summarised. Additionally, the comprehension of POM pathways and the corresponding pictorial depiction are discussed and provided in this paper.
\end{abstract}

\section{Introduction}

Fossil fuels are our primary energy source that have a significant impact on human welfare over the past few decades [1]. However, increasing energy demand from global population has led to severe energy shortage crisis $[2,3]$. Thus, the rapid growth in energy demand induced by the increase in global population, depletion of non-renewable fossil fuels, and overabundant emissions of anthropogenic carbon dioxide $\left(\mathrm{CO}_{2}\right)$ greenhouse gas from intensive industrial combustions have accelerated the necessity of alternative and renewable energy sources [4].

Syngas (a mixture of hydrogen $\left(\mathrm{H}_{2}\right)$ and carbon monoxide $(\mathrm{CO})$ ) appears as a highly potential candidate among renewable energy sources, which provides flexible building blocks for synthetic fuel production via Fischer-Tropsch synthesis (FTS) and its derivatives including methanol, dimethyl ether (DME), and methyl tert-butyl ether (MTBE) in petrochemical industries [5-7]. Steam reforming of methane (SRM, see Equation (1)) is generally utilised as the conventional method for industrial syngas production with regard to economic perspective [8], whereas in respect of environmental concerns, dry reforming

* Corresponding author: aishahaj@utm.my 
of methane (DRM. cf. Equation (2)) is able to convert unwanted $\mathrm{CO}_{2}$ gas into value-added syngas products $[9,10]$. However, the resulting $\mathrm{H}_{2} / \mathrm{CO}$ ratios of these two technologies are inappropriate for the major downstream production such as FTS and methanol generation, which requires a practical $\mathrm{H}_{2} / \mathrm{CO}$ ratio of 2 . As a result, the implementation of SRM (or DRM) technology probably requires ancillary processes such as purification and separation for tuning the $\mathrm{H}_{2} / \mathrm{CO}$ ratio, leading to a rise in capital expenditure. Catalytic partial oxidation of methane (POM, see Equation (3)) has therefore appeared as the attractive technology to yield the $\mathrm{H}_{2} / \mathrm{CO}$ ratio of 2 for subsequent downstream production.

$$
\begin{array}{ll}
\mathrm{CH}_{4}+\mathrm{H}_{2} \mathrm{O} \rightarrow 3 \mathrm{H}_{2}+\mathrm{CO} & \Delta \mathrm{H}_{298 \mathrm{~K}}=+206 \mathrm{~kJ} \mathrm{~mol}^{-1} \\
\mathrm{CH}_{4}+\mathrm{CO}_{2} \rightarrow 2 \mathrm{H}_{2}+2 \mathrm{CO} & \Delta \mathrm{H}_{298 \mathrm{~K}}=+247 \mathrm{~kJ} \mathrm{~mol}^{-1} \\
\mathrm{CH}_{4}+0.5 \mathrm{O}_{2} \rightarrow 2 \mathrm{H}_{2} \quad \mathrm{CO} & \Delta \mathrm{H}_{298 \mathrm{~K}}=-126 \mathrm{~kJ} \mathrm{~mol}^{-1}
\end{array}
$$

Perovskite oxides with $\mathrm{ABO}_{3}$ structure have recently attracted substantial attention in various realms of solid-state chemistry, including catalysis. Over the past few decades, extensive investigations for POM reaction and relevant findings have mainly been systematised based on actual experimental studies [11-13]. Nevertheless, summaries of POM performance over perovskite catalysts are still little-known. Thus, in this paper, emphasis has been placed on the perovskite catalyst system and the process chemistry of POM, and several opinions and outlooks are provided in the conclusion.

\section{Process chemistry of POM reaction}

Chemical processes are fundamentally dominated by the thermodynamic nature of reaction equilibrium. Numerous reaction routes could concomitantly occur to produce desired products and unwanted side products within the same system. In fact, POM process consists of such a system. The complexity of this system probably involves multiple primary reactions for syngas production (viz, SRM (Equation (1)), DRM (Equation (2)), and POM (Equation (3))) and some side reactions comprising of non-coke reactions (see Equations (4)-(6)) and coke forming reactions (cf. Equations (8)-(10)). Apart from direct POM process, a two-step combustion-reforming process also contributes to the production of syngas, in which $\mathrm{CO}_{2}$ and $\mathrm{H}_{2} \mathrm{O}$ produced from the total combustion of methane could subsequently react with the remaining methane $\left(\mathrm{CH}_{4}\right)$ to yield $\mathrm{H}_{2}$ and $\mathrm{CO}$, known as DRM and SRM reactions $[6,14]$.

$$
\begin{gathered}
\mathrm{CH}_{4}+2 \mathrm{O}_{2} \rightarrow 2 \mathrm{H}_{2} \oplus \quad \mathrm{CO}_{2} \quad \Delta \mathrm{H}_{298 \mathrm{~K}}=-803 \mathrm{~kJ} \mathrm{~mol}^{-1} \\
\mathrm{CO}+0.5 \mathrm{O}_{2} \rightarrow \mathrm{CO}_{2} \quad \Delta \mathrm{H}_{298 \mathrm{~K}}=-288 \mathrm{~kJ} \mathrm{~mol}^{-1} \\
\mathrm{H}_{2}+0.5 \mathrm{O}_{2} \rightarrow \mathrm{H}_{2} \mathrm{O} \quad \Delta \mathrm{H}_{298 \mathrm{~K}}=-286 \mathrm{~kJ} \mathrm{~mol}^{-1} \\
\mathrm{H}_{2}+\mathrm{CO}_{2} \quad \mathrm{H}_{2} \mathrm{O}+\mathrm{CO} \quad \Delta \mathrm{H}_{298 \mathrm{~K}}=+41 \mathrm{~kJ} \mathrm{~mol}^{-1} \\
\mathrm{CO}_{2}+\mathrm{C} \quad 2 \mathrm{CO} \quad \Delta \mathrm{H}_{298 \mathrm{~K}}=+172 \mathrm{~kJ} \mathrm{~mol}^{-1} \\
\mathrm{CH}_{4} \rightarrow 2 \mathrm{H}_{2}+\mathrm{C} \quad \Delta \mathrm{H}_{298 \mathrm{~K}}=+75 \mathrm{~kJ} \mathrm{~mol}^{-1} \\
\mathrm{H}_{2} \mathrm{O}+\mathrm{C} \quad \mathrm{CO}+\mathrm{H}_{2} \quad \Delta \mathrm{H}_{298 \mathrm{~K}}=+131 \mathrm{~kJ} \mathrm{~mol}^{-1}
\end{gathered}
$$

In the brief overview of POM, York et al. [14] reported that POM was only able to produce high $\mathrm{H}_{2}$ and $\mathrm{CO}$ yield at high temperature of $850{ }^{\circ} \mathrm{C}$ and above, whereas nonequilibrium product distributions were obtained at the temperature below $850{ }^{\circ} \mathrm{C}$. In addition, Zhu et al. [15] reported similar findings in their study of POM thermodynamic 
analysis. Regardless of the concentration of $\mathrm{CH}_{4}$, they proposed that $\mathrm{CH}_{4}$ only partially participated in POM reaction at low temperature region, resulting in low product yield due to the high kinetic barrier to the reaction. However, at high temperature region, $\mathrm{H}_{2}$ and $\mathrm{CO}$ yields increased drastically possibly due to the dominance of POM [15]. In addition, SRM and DRM could contribute to syngas production since these endothermic reactions are thermodynamically favourable at high temperature region.

As POM results in volume expansion based on the stoichiometric reaction equation (see Equation (3)), rising pressure on POM reportedly led to the reduction in $\mathrm{CH}_{4}$ conversion, as well as $\mathrm{H}_{2}$ and $\mathrm{CO}$ product yields [14]. Interestingly, York et al. also suggested that the total combustion reaction (see Equation (4)) was more likely independent from gas expansion effect during POM, thus the increasing pressure could favourably accelerate the formation rate of $\mathrm{CO}_{2}$ and $\mathrm{H}_{2} \mathrm{O}$ as given in Equations (5) and (6) instead of the main reactions (viz, SRM, DRM, and SRM). In addition, Zhu et al. proposed that the pressure effect on syngas production was only significant at the temperature ranging of 400 to 1200 ${ }^{\circ} \mathrm{C}$ based on their thermodynamic and kinetic simulation results [15]. This behaviour further corroborates that the dominance of reactions is mainly governed by the reaction temperature to achieve high $\mathrm{H}_{2}$ and $\mathrm{CO}$ yields.

\section{Perovskite catalysts for POM reaction}

Numerous studies about the development of perovskite catalysts for POM reaction have been reported in the literature due to its excellent properties and benefits, as well as catalytic activity and stability as summarised in Table 1. Perovskite catalysts are generally presented by the formula of $\mathrm{ABO}_{3}$, in which $\mathrm{A}$ and $\mathrm{B}$ are two metal cations with different sizes [16]. With respect to the perovskite structure, the B-site cation is octahedrally surrounded and the A-site cation is positioned at the vacancy produced between these octahedra. These structures offer feasible alternation of unit cell dimensions by the replacement of $\mathrm{A}$ ion and hence, varying the covalence of $\mathrm{B}-\mathrm{O}$ bond in the $\mathrm{ABO}_{3}$ structure [17]. In fact, the formation of lattice defects induced by A-site or B-site cation substitutions enhances oxygen $\left(\mathrm{O}_{2}\right)$ adsorption and mobility within the lattice structure, hence promoting catalytic performance [18]. In many studies, both A and B-site ions can be partly replaced by other metals to produce multi-cation substituted perovskites with the formula of $\mathrm{AA}^{\prime} \mathrm{BB}^{\prime} \mathrm{O}_{3}$ [16-19]. Figure 1 demonstrates the reaction processes during POM over perovskites. 


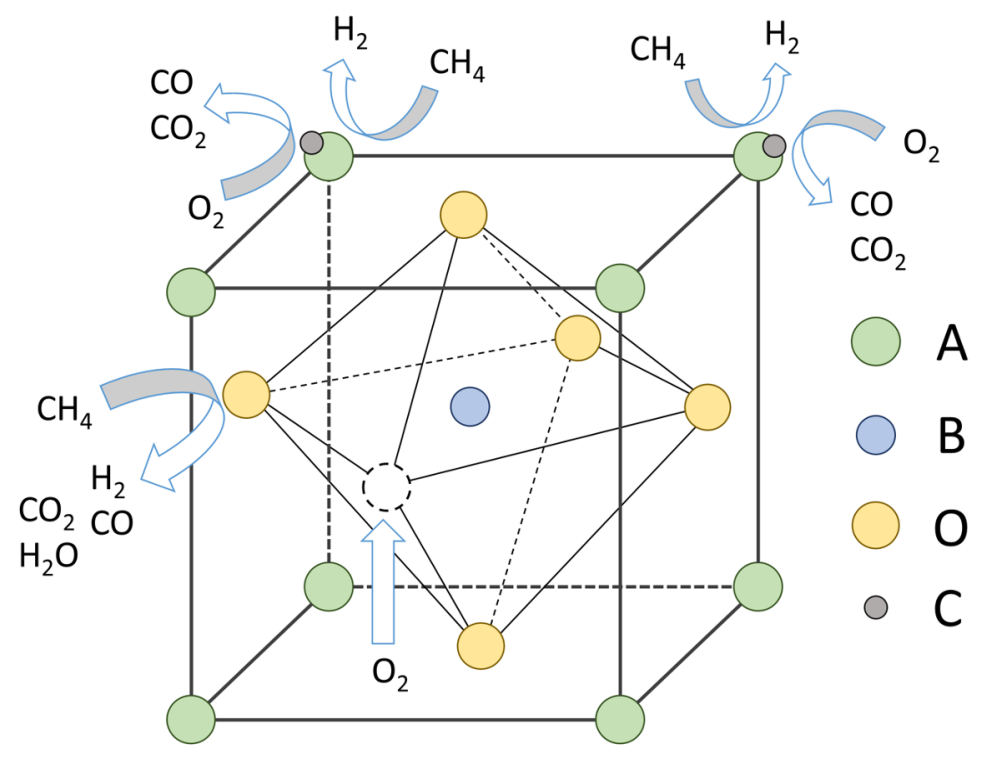

Fig. 1. Pictorial depiction of reaction processes during POM over perovskites.

As previously mentioned, POM possesses two routes of reaction pathways to produce syngas. In the investigation of $\mathrm{La}_{1-\mathrm{x}} \mathrm{Sr}_{\mathrm{x}} \mathrm{FeO}_{3}$ as an oxygen carrier for POM, Zhao et al. [20] found that the increasing strontium $(\mathrm{Sr})$ composition in perovskites enhanced the adsorption of $\mathrm{O}_{2}$ on catalyst surface, thus suppressing coke formation. However, the improved $\mathrm{O}_{2}$ adsorption reduced both $\mathrm{CH}_{4}$ conversion (from $95 \%$ to $56 \%$ ) and $\mathrm{H}_{2}$ selectivity (from $86 \%$ to $76 \%$ ). From the above observations, Zhao et al. [20] proposed that the enhanced $\mathrm{O}_{2}$ adsorption led to the excessive adsorbed oxygen (from oxygen reactant) on catalyst surface, favouring complete oxidation of $\mathrm{CH}_{4}$ (see Equation (4)) whereas the lattice $\mathrm{O}_{2}$ originated from the reduction of $\mathrm{Fe}^{3+}$ to $\mathrm{Fe}^{2+}$ was appropriate for the direct POM (cf. Equation (3)) pathway. Dedov et al. [21] conducted experimental POM studies over the rare earth-alkali earth cobaltate-based catalyst, namely $\mathrm{NdCaCoO}_{3.96}, \mathrm{LaSrCoO}_{4}$, and $\mathrm{La}_{1.25} \mathrm{Sr}_{0.75} \mathrm{CoO}_{4.03}$. $\mathrm{NdCaCoO}_{3.96}$ exhibited the highest $\mathrm{CH}_{4}$ conversion of $88 \%$ and $\mathrm{CO}$ selectivity of $90 \%$ in comparison to that of $\mathrm{LaSrCoO}_{4}$ and $\mathrm{La}_{1.25} \mathrm{Sr}_{0.75} \mathrm{CoO}_{4.03}$. They assigned the excellent catalytic activity of $\mathrm{NdCaCoO}_{3.96}$ to the easier formation of $\mathrm{Nd}$ and $\mathrm{Ca}$ oxides, as well as metallic Co phase during the reduction in POM, as demonstrated by $\mathrm{H}_{2}$ temperatureprogrammed reduction $\left(\mathrm{H}_{2}-\mathrm{TPR}\right)$ data [21].

In the paper of POM over La-Ca-M-(Al)-O ( $\mathrm{M}=\mathrm{Co}, \mathrm{Cr}, \mathrm{Fe}$, and $\mathrm{Mn})$ perovskites, Cihlar Jr. et al. [22] reported the order of catalytic activity as La-Ca-Co-(Al)-O > La-Ca$\mathrm{Fe}-(\mathrm{Al})-\mathrm{O}>\mathrm{La}-\mathrm{Ca}-\mathrm{Mn}-(\mathrm{Al})-\mathrm{O}>\mathrm{La}-\mathrm{Ca}-\mathrm{Cr}-(\mathrm{Al})-\mathrm{O}$. The improvement of catalytic activity was ascribed to the rise in the strength of $\mathrm{M}-\mathrm{O}$ bond in $\mathrm{La}-\mathrm{Ca}-\mathrm{M}-(\mathrm{Al})-\mathrm{O}$ catalysts and growing stability of the perovskite systems during $\mathrm{H}_{2}$ reduction. Based on the TPR/TPO experiments, Cihlar Jr. et al. proposed that POM over La-Ca-M-(Al)-O system could be interpreted as a two-step mechanism, known as combustion-reforming process, in which the total oxidation of $\mathrm{CH}_{4}$ produced $\mathrm{CO}_{2}$ and $\mathrm{H}_{2} \mathrm{O}$, followed by SRM and DRM to yield $\mathrm{H}_{2}$ and $\mathrm{CO}$ [22]. Palcheva et al. reported that $\mathrm{Rh}$ promotion on $\mathrm{La}_{0.75} \mathrm{Sr}_{0.25}\left(\mathrm{Fe}_{0.8} \mathrm{Co}_{0.2}\right)_{1-\mathrm{x}} \mathrm{Ga}_{\mathrm{x}} \mathrm{O}_{3-\delta}$ catalysts could improve the reducibility of perovskite oxides and thus, enhancing $\mathrm{CH}_{4}$ dissociation [23]. However, the increase in gallium (Ga) addition on rhodium (Rh)promoted perovskite oxides reportedly decreased the catalytic performance, possibly owing to the metal agglomeration induced by reduction and oxidation cycles of perovskite particles. Thus, they concluded that perovskites reducibility and dispersion degree of $\mathrm{Rh}$ 
particles were the crucial key to the catalytic behaviour in order to obtain excellent POM performance.

Table 1. List of catalytic performance for recently employed catalysts in POM reaction.

\begin{tabular}{|c|c|c|c|c|c|c|c|}
\hline \multirow{3}{*}{ Catalyst } & \multirow{3}{*}{$\underset{\text { Ratio }}{\mathbf{C H}_{4} / \mathbf{O}_{2}}$} & \multirow{3}{*}{$\begin{array}{c}\mathbf{T} \\
\left({ }^{\circ} \mathbf{C}\right)\end{array}$} & \multirow{3}{*}{$\begin{array}{c}\text { Gas Hourly } \\
\text { Space } \\
\text { Velocity } \\
\left(\mathrm{L} \mathrm{gcat}^{-1} \mathbf{h}^{-1}\right) \\
\end{array}$} & \multicolumn{3}{|c|}{ Performance } & \multirow{3}{*}{ Ref. } \\
\hline & & & & \multirow{2}{*}{$\begin{array}{c}\begin{array}{c}\text { Conversion } \\
(\%)\end{array} \\
\mathrm{CH}_{4} \\
\end{array}$} & \multicolumn{2}{|c|}{$\begin{array}{c}\text { Selectivity } \\
(\%)\end{array}$} & \\
\hline & & & & & $\mathrm{H}_{2}$ & $\mathrm{CO}$ & \\
\hline $\mathrm{LaFeO}_{3}$ & - & 850 & 12 & 95 & 86 & 6 & [20] \\
\hline $\mathrm{La}_{0.7} \mathrm{Sr}_{0.3} \mathrm{FeO}_{3}$ & - & 850 & 12 & 63 & 81 & 44 & {$[20]$} \\
\hline $\mathrm{La}_{0.5} \mathrm{Sr}_{0.5} \mathrm{FeO}_{3}$ & - & 850 & 12 & 68 & 78 & 36 & {$[20]$} \\
\hline $\mathrm{La}_{0.1} \mathrm{Sr}_{0.9} \mathrm{FeO}_{3}$ & - & 850 & 12 & 56 & 76 & 85 & {$[20]$} \\
\hline $\mathrm{NdCaCoO}_{3.96}$ & $2: 1$ & 900 & 20 & 88 & - & 90 & [21] \\
\hline $\mathrm{LaSrCoO}_{4}$ & $2: 1$ & 900 & 20 & 37 & - & 58 & [21] \\
\hline $\mathrm{La}_{1.25} \mathrm{Sr}_{0.75} \mathrm{CoO}_{4.03}$ & $2: 1$ & 900 & 20 & 33 & - & 31 & [21] \\
\hline $\mathrm{La}_{0.5} \mathrm{Ca}_{0.5} \mathrm{Co}_{0.7} \mathrm{Al}_{0.3} \mathrm{O}_{3-\delta}$ & $2: 1$ & 900 & 36 & 99 & 99 & 99 & {$[22]$} \\
\hline $\mathrm{La}_{0.5} \mathrm{Ca}_{0.5} \mathrm{Cr}_{0.7} \mathrm{Al}_{0.3} \mathrm{O}_{3-\delta}$ & $2: 1$ & 900 & 36 & 56 & 75 & 80 & {$[22]$} \\
\hline $\mathrm{La}_{0.5} \mathrm{Ca}_{0.5} \mathrm{Fe}_{0.7} \mathrm{Al}_{0.3} \mathrm{O}_{3-\delta}$ & $2: 1$ & 900 & 36 & 79 & 88 & 88 & {$[22]$} \\
\hline $\mathrm{La}_{0.5} \mathrm{Ca}_{0.5} \mathrm{Mn}_{0.7} \mathrm{Al}_{0.3} \mathrm{O}_{3-\delta}$ & $2: 1$ & 900 & 36 & 74 & 81 & 84 & {$[22]$} \\
\hline $\mathrm{La}_{0.75} \mathrm{Sr}_{0.25} \mathrm{Fe}_{0.6} \mathrm{Co}_{0.15} \mathrm{Ga}_{0.25} \mathrm{O}_{3-\delta}$ & $1: 1$ & 600 & 18.6 & 17 & - & - & [23] \\
\hline $\mathrm{Rh} / \mathrm{La}_{0.8} \mathrm{Sr}_{0.2} \mathrm{Fe}_{0.8} \mathrm{Co}_{0.2} \mathrm{O}_{3-\delta}$ & $1: 1$ & 600 & 18.6 & 82 & - & 32 & [23] \\
\hline $\mathrm{Rh} / \mathrm{La}_{0.75} \mathrm{Sr}_{0.25} \mathrm{Fe}_{0.6} \mathrm{Co}_{0.15} \mathrm{Ga}_{0.1} \mathrm{O}_{3-\delta}$ & $1: 1$ & 600 & 18.6 & 97 & - & 85 & [23] \\
\hline $\mathrm{Rh} / \mathrm{La}_{0.75} \mathrm{Sr}_{0.25} \mathrm{Fe}_{0.6} \mathrm{Co}_{0.15} \mathrm{Ga}_{0.25} \mathrm{O}_{3-\delta}$ & $1: 1$ & 600 & 18.6 & 83 & - & 97 & [23] \\
\hline $\mathrm{Rh} / \mathrm{La}_{0.75} \mathrm{Sr}_{0.25} \mathrm{Fe}_{0.6} \mathrm{Co}_{0.15} \mathrm{Ga}_{0.4} \mathrm{O}_{3-\delta}$ & $1: 1$ & 600 & 18.6 & 66 & - & 100 & [23] \\
\hline
\end{tabular}

\section{Conclusion and outlooks}

POM is a promising substitute for other conventional reforming processes for syngas production as it offers the adaptable adjustment of $\mathrm{H}_{2} / \mathrm{CO}$ ratios by manipulating feed composition. In addition, $\mathrm{O}_{2}$ oxidising agent in POM reaction could significantly diminish carbon formation and thus, improve catalytic activity and stability.

However, the bibliographic knowledge about POM mechanism is still vague due to the complexity of this reaction. In order to improve the combined benefits of metals and supports, the use of innovative catalyst synthesis approaches could extensively influence the physicochemical properties of catalysts (i.e., surface metal dispersion and degree of metal-support interaction). Additionally, the best-fit kinetic modelling developed from the fundamental POM mechanistic steps is important in order to efficiently fabricate a functional catalyst. Therefore, future studies of suitable and proper catalyst preparation 
techniques and POM kinetics should be considered in order to improve catalytic performance and stability for the industrial application of POM process.

The authors gratefully acknowledge the financial support from Universiti Teknologi Malaysia via Research University Grant No. $19 \mathrm{H} 04$ for this work.

\section{References}

1. D. Pakhare, J. Spivey, Chem. Soc. Rev. 43, 7813-7837 (2014)

2. A. Goeppert, M. Czaun, J.P. Jones, G.S. Prakash, G.A. Olah, Chem. Soc. Rev. 43, 7995-8048 (2014)

3. International Energy Agency, World energy outlook 2017 (2017)

4. T.D.S. Veras, T.S. Mozer, D.D.C.R.M.D. Santos, A.D.S. César, Int. J. Hydrogen Energy 42, 2018-2033 (2017)

5. W. Wang, S. Wang, X. Ma, J. Gong, Chem. Soc. Rev. 40, 3703-372 (2011)

6. M. Usman, W.M.A. Wan Daud, H.F. Abbas, Renew. Sustain. Energy Rev. 45, 710-744 (2015)

7. B. Abdullah, N.A.A. Ghani, D.V.N. Vo, J. Clean. Prod. 162, 170-185 (2017)

8. W. Nabgan, T.A.T. Abdullah, R. Mat, B. Nabgan, Y. Gambo, M. Ibrahim, A. Ahmad, A.A. Jalil, S. Triwahyono, I. Saeh, Renew. Sust. Energy Rev. 79, 347-357 (2017)

9. S.M. Sidik, A.A. Jalil, S. Triwahyono, T.A.T. Abdullah, A. Ripin, RSC Adv. 5, 37405-37414 (2015)

10. S.M. Sidik, S. Triwahyono, A.A. Jalil, M.A.A. Aziz, N.A.A. Fatah, L.P. The, J. $\mathrm{CO}_{2}$ Util. 13, 71-80 (2016)

11. Y.H. Hu, E. Ruckenstein, J. Phys. Chem. A 102, 10568-10571 (1998)

12. E. Finocchio, G. Busca, P. Forzatti, G. Groppi, A. Beretta, Langmuir 23, 10419-10428 (2007)

13. Y. Zhu, S. Zhang, J.J. Shan, L. Nguyen, S. Zhan, X. Gu, F. Tao, ACS Catal. 3, 2627-2639 (2013)

14. A.P. York, T. Xiao, and M.L. Green, Top. Catal. 22, 345-358 (2003)

15. J. Zhu, D. Zhang, K.D. King, Fuel 80, 899-905 (2001)

16. C.-J. Liu, J. Ye,J. Jiang, Y. Pan, ChemCatChem 3, 529-541 (2011)

17. M.-S. Fan, A.Z. Abdullah, S. Bhatia, ChemCatChem 1, 192-208 (2009)

18. S. Kawi, Y. Kathiraser, J. Ni, U. Oemar, Z. Li, E.T. Saw, ChemSusChem 8, 35563575 (2015)

19. M.M. Nair, S. Kaliaguine, New J. Chem. 40, 4049-4060 (2016)

20. K. Zhao, F. He, Z. Huang, A. Zheng, H. Li, Z. Zhao, Chinese J. Catal. 35, 11961205 (2014)

21. A.G. Dedov, A.S. Loktev, D.A. Komissarenko, K.V. Parkhomenko, A.-C. Roger, O.A. Shlyakhtin, G.N. Mazo, I.I. Moiseev, Fuel Process. Technol. 148, 128-137 (2016) 
22. J. Cihlar Jr., R. Vrba, K. Castkova, J. Cihlar, Int. J. Hydrogen Energy 42, 1992019934 (2017)

23. R.Palcheva, U. Olsbye, M. Palcut, P. Rauwel, G. Tyuliev, N. Velinov, H.H. Fjellvag, Appl. Surf. Sci. 357, 45-54 (2015) 